\title{
3D Tomographic Imaging of P Wave Velocity Structure Beneath Java Island using Fast Marching Tomography Method
}

\author{
Uswatun Chasanah $^{1}$, Bagus Jaya Santosa ${ }^{2}$
}

\begin{abstract}
Java Island one of the best locations for geophysics research, as it's located near the edge of the junction of continental Eurasia Plate and the Indo-Australia Plate with the movement of the plates $6 \mathrm{~cm} / \mathrm{year}$. Its needed the accurate imaging of subsurface structure to understanding complex tectonic setting. The first arrival time from local earthquake of Java $(6,360-9,150 \mathrm{~S}$ and 105,890-115,540 E) with magnitude greater than 4,5 Mw occurred from 2011 until 2013 recorded by local network seismograph has been inverted for three dimensional variation of the depth to the $P$ wave velocity in the Java island. At the same time, earthquake hypocenter location has been corrected simultaneous. This research apply a new tomographic inversion scheme FMTOMO that has been developed by Rawlinson (2004). The results of inversion show that there are three layer in $100 \mathrm{~km}$ from the surface at continental plate side (Eurasia). The continental upper crust has $P$ wave velocity variation about 4-5,5 km/s in the depth until $30 \mathrm{~km}$ from the surface. There are low velocity anomaly inclined towards the slab which probably have associated with shallow earthquake along the slab.
\end{abstract}

Keywords - P-wave, seismic tomography, Java Island

\section{INTRODUCTION}

$\mathrm{T}$ he subduction zones on the crust of the Earth is related with the seismic and volcanic activity. Java island, located at the junction of two major tectonic plates (IndoAustralian plate and Eurasian plate), is formed by a complex mosaic of oceanic plates, island arcs, continental shelf and crustal fragments [1]. Tectonic stucture of Java island is dominated by the almost orthogonal convergence between the Australian plate and Eurasia $(67-70 \mathrm{~mm} / \mathrm{year}$, today).

The Indo-Australia plate is pushing the Eurasia plate. In north of Java island, Indo-Australia plate is moving 100200 under the Eurasian plate [2]. The deeper slab beneath Java, appearing as an inclined high-velocity feature, seems to be continuous from the Earth's surface to the lower mantle [3].

To understand the mechanisms of the process of tectonic activity, seismicity and volcanism, we need some tools. Seismic tomography is one of the most powerful tools to obtain these constraints [4]. This is a form of seismic traveltime inversion that is used to constrain $2 \mathrm{D}$ and $3 \mathrm{D}$ models of the Earth represented by a significant number of parameters [5]. Actually the earthquake cause the propagate of seismic wave that bring some information about interior structure of the earth. Seismic data in seismograph represent one of the most valuable resources and important information for investigating the internal structure and composition of the earth.

\footnotetext{
${ }^{1}$ Uswatun Chasanah and Bagus Jaya Santosa are with Department of Physics, Institut Teknologi Sepuluh Nopember, Surabaya, 60111, Indonesia. $\quad$ E-mail: chasanah14@mhs.physics.its.ac.id; uswah23@gmail.com; bjs@physics.its.ac.id
}

The accurate of hypocentre location is one of the main things when studying the seismicity of the area within the parameters of the earthquake because there is important information from ongoing seismotectonic process [6]. The earthquake parameters are usually magnitude, origin time, epicentre and depth. The accuracy of seismic parameter calculation is highly dependent on the structure of seismic wave velocity models used. The aim of this local scale studies on this paper is to explore the deep structure of slabs beneath Java Island by means of tomographic imaging using $\mathrm{P}$ wave phases.

\section{METHOD}

The $431 \mathrm{P}$ wave phases was picked from waveform 3 components that recorded by 35 local network seismograph. And it was inverted using FMTOMO that calculated using fast marching tomography method. This processes obtaining the value of $3 \mathrm{D}$ velocity to determine the real structure of tectonic settings under the Java island.

Origin time value of $\mathrm{P}$ waves is obtained by picking the seismic waveform from each station. In this study, picking process of arrival time of $\mathrm{P}$ wave is using software Seisgram2K (Figure. 1).

FMTOMO uses the fm3d package to solve the forward problem. Fm3d is based on the multi-stage Fast Marching Method (FMM), a grid based eikonal solver (1) that implicitly tracks the evolution of waveform in 3-D layered media. For more details, refer to Sethian (1996), Sethian\& Popovici (1999), Sethian (1999) and Popovici \& Sethian (2002) [7], [8]. The eikonal equation states that the magnitude of the traveltime gradient at any point along a wave front is equal to the inverse of the wavespeed at that point [9] and may be written as: 
$\left|\nabla_{x} T\right|=s(x)$

(1) slowness [10].

where $\nabla_{x}$ is the gradient operator, $T$ is traveltime and $s(x)$ is

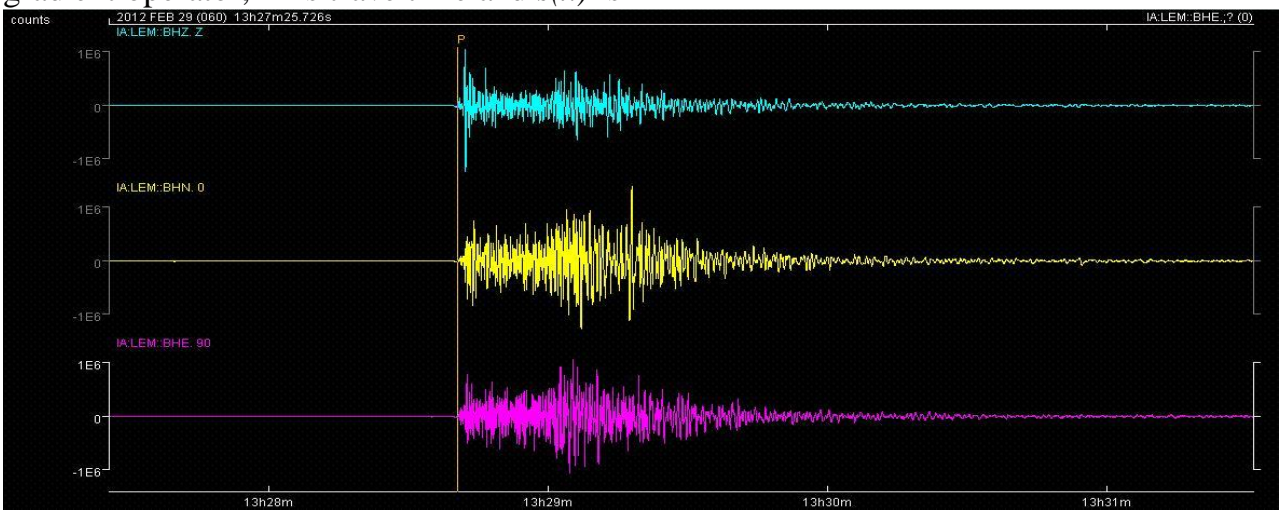

Figure 1. Picking process the arrival time of $\mathrm{P}$ wave using software Seisgram2K

If we represent some elastic property of the subsurface (e.g. velocity) by a set of model parameters $m$, then a set of data (e.g. traveltimes) $d$ can be predicted for a given sourcereceiver array by line integration through the model. The inversion step, which involves the adjustment of the model parameters $m$ to better satisfy the observed data $d_{o b s}$ through the known relationship.

$$
d=G m
$$

In travel time tomography, the functional $G$ is non-linear because the ray path depends on the velocity structure [11]. For an initial estimate $m_{0}$ of the model parameters, comparing this equation (3)

$$
d=G m_{0}
$$

with the observed travel time $d_{o b s}$ gives an indication of the accuracy of the model. The misfit can be quantified by constructing an objective function $S(m)(4)$, consisting of a weighted sum of data misfit and regularization terms, that is to be minimized. The objective function is given (4).

$$
\begin{aligned}
& S(m)=\frac{1}{2}\left(G(m)-d_{o b s}\right)^{T} C_{d}^{-1}\left(G(m)-d_{o b s}\right)+\varepsilon(m- \\
& \left.m_{0}\right)^{T} C_{m}^{-1}\left(m-m_{0}\right)+\eta m^{T} D^{T} D m
\end{aligned}
$$

The steps required to produce a tomographic image from seismic data can thus be defined as follows (adapted from nick Rawlinson et al.):

1. Model parameterization: The seismic structure of the region being mapped is defined in terms of a set of unknown model parameters.

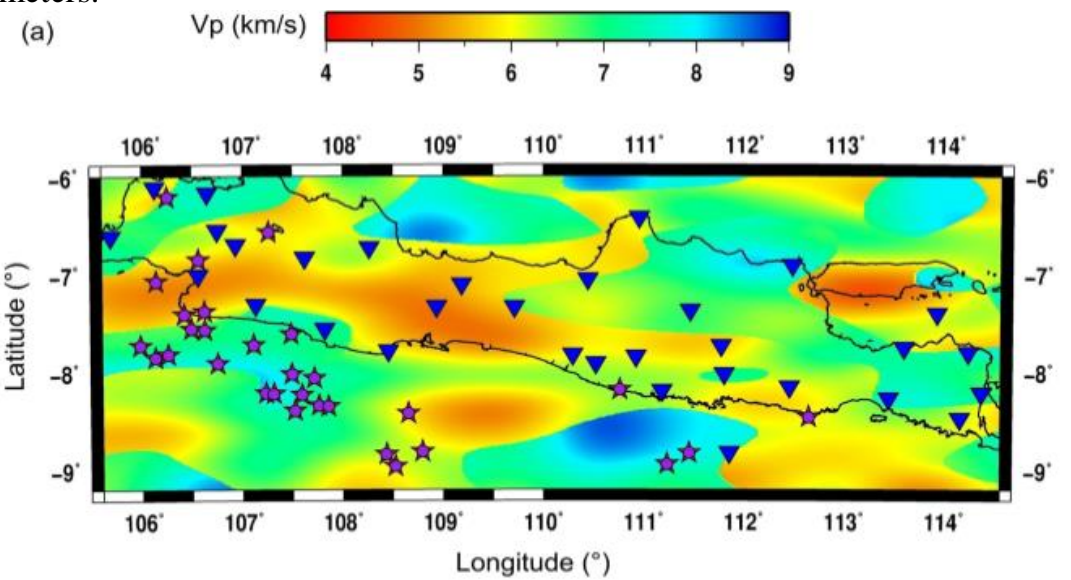

Figure 2. The resulting distribution of P-velocity anomalies after the inversion of six iterations is shown in this picture. Purple stars mark sources earthquake (epicenter) of the BMKG-IA catalogue, and blue triangles in profile marks the station that recorded the earthquake signals.
2. Forward calculation: A procedure is defined for the calculation of model data (traveltimes) given a set of values for the model parameters.

Inversion: Automated adjustment of the model parameter values with the object of better matching the model data to the observed data.

\section{RESULT AND ANALYSIS}

The tomographic solution model, obtained after six iterations of the non-linear scheme, is shown in Figure 2, Figure 3, Figure 4 and Figure 5. In horizontal cross section and vertical cross sections. The rms values of the residuals in six iterations are presented in Table 3. The ak135 velocity model was used for the reference, or starting, velocity model. Damping $(\epsilon)$ and smoothing $(\eta)$ values were chosen to solve variations in deep mantle and crustal structure may account for some of the data misfit. We used a 20-dimensional subspace scheme on six iterations to solve both $\mathrm{P}$ inversions. However, in some cases the subspace was reduced by Singular Value Decomposition (SVD) orthogonalization to remove unnecessary basis vectors during the inversion step. Iterations are repeated until the contribution of the next cycle becomes negligible. In case of our study, six iterations were enough to achieve sufficient convergence [12]. 


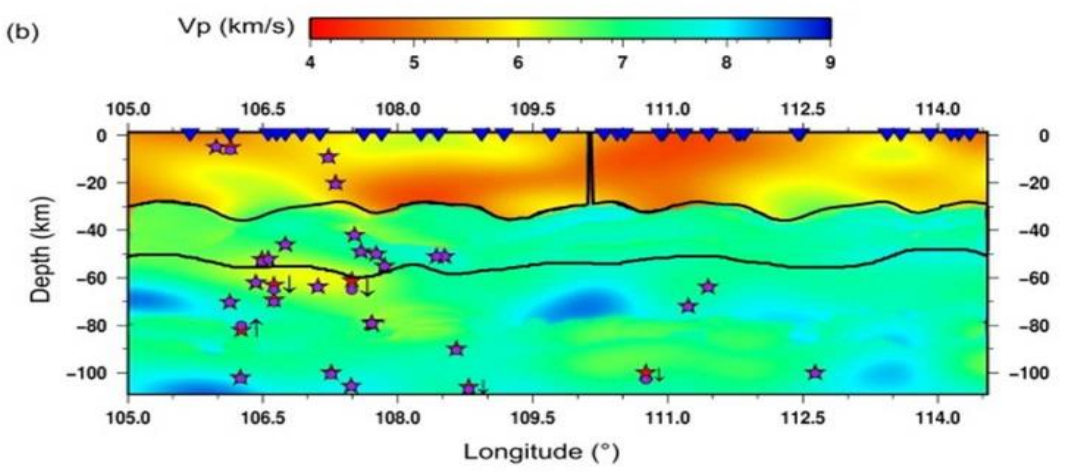

Figure 3. P-velocity model presented in vertical cross sections. Profile locations are shown in the map on slide before. Purple dots mark hypocentres of the BMKG-IA catalogue before relocation of hypocenter, red stars in profile marks the hypocentre of the Java earthquake after relocation, and the vector marks the preposition of location hypocenter before and after relocation.

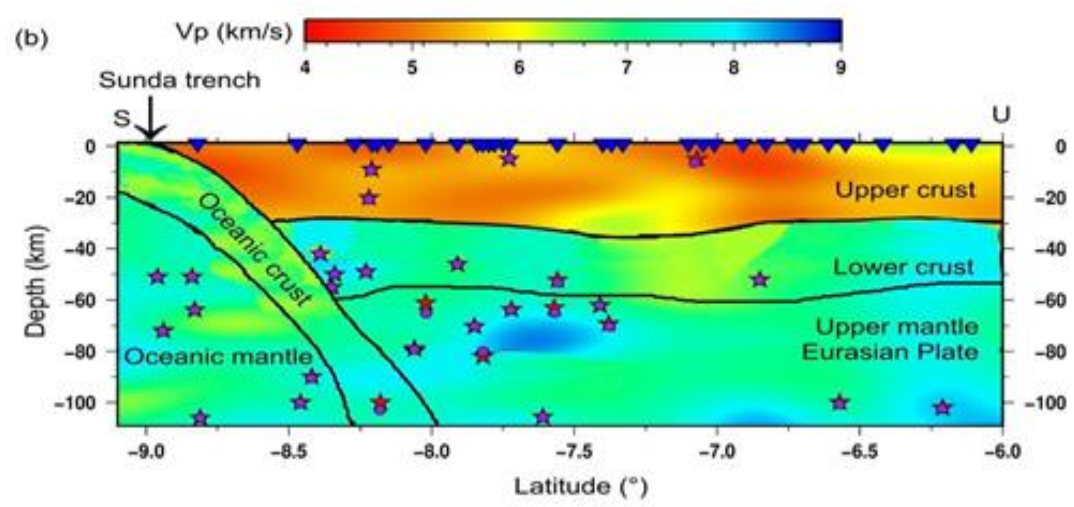

Figure 4. A large low-velocity anomaly in the upper crust northward of the oceanic crust. There are three layer in $100 \mathrm{~km}$ from the surface at continental plate side (Eurasia). The upper crust, lower crust and upper mantle. The oceanic plate (Indo Australia) have two layer in $100 \mathrm{~km}$ from the surface. The oceanic crust and the oceanic mantle.
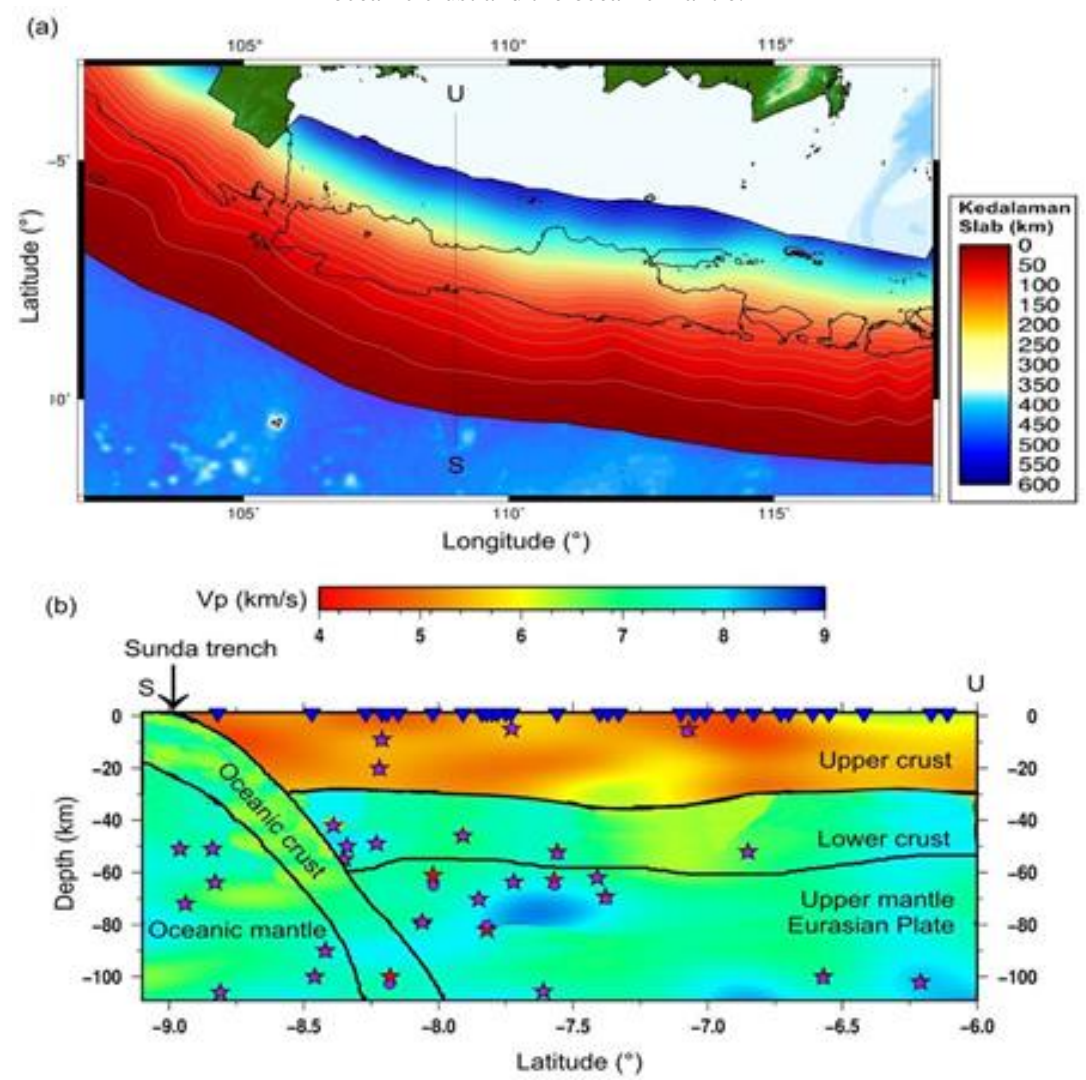

Figure 5. (a) Sketch of slab subduction of Java island, (b) Sketch and interpretation of the velocity structure in Java island. The oceanic plate pushes northward and subduct under Java. Stresses accumulate in the near of slab of oceanic crust region where fractures occur. The earthquake hypocentre is located just below this level ( $\sim 0 \mathrm{~km}$ depth). This implies that it is located in the rigid crust that is the most probable location for stress accumulation. 
TABLE 1.

SUMMARY OF RESULT INTERPRETATION VERTICAL LONGITUDE CROSSSECTION

\begin{tabular}{cccc}
\hline \hline \multirow{2}{*}{$\begin{array}{c}\text { Layer } \\
\text { Number }\end{array}$} & Layer Name & $\begin{array}{c}\text { Estimation Depth } \\
(\mathrm{km})\end{array}$ & $\begin{array}{c}\text { Estimation Vp } \\
(\mathrm{km} /)\end{array}$ \\
\cline { 2 - 4 } 1 & $\begin{array}{c}\text { Continental Upper } \\
\text { Crust }\end{array}$ & $0-30$ & $4-5,5$ \\
2 & $\begin{array}{c}\text { Continental Lower } \\
\text { Crust }\end{array}$ & $30-50$ & $6,5-7$ \\
3 & $\begin{array}{c}\text { Continental Upper } \\
\text { Mantle }\end{array}$ & $50-100$ & $6,5-8,5$ \\
\hline \hline
\end{tabular}

TABLE 2.

SUMMARY OF RESULT INTERPRETATION VERTICAL LATITUDE CROSSSECTION

\begin{tabular}{ccccc}
\hline \hline \multirow{2}{*}{$\begin{array}{c}\text { Layer } \\
\text { Kind }\end{array}$} & $\begin{array}{c}\text { Layer } \\
\text { Number }\end{array}$ & Layer Name & $\begin{array}{c}\text { Estimation } \\
\text { Depth }(\mathrm{km})\end{array}$ & $\begin{array}{c}\text { Estimation } \\
\mathrm{Vp}(\mathrm{km} /)\end{array}$ \\
\cline { 3 - 5 } $\begin{array}{c}\text { Continental } \\
\text { plate }\end{array}$ & 1 & $\begin{array}{c}\text { Continental Upper } \\
\text { Crust }\end{array}$ & $0-30$ & $4-5,5$ \\
& 2 & $\begin{array}{c}\text { Continental Lower } \\
\text { Crust }\end{array}$ & $30-50$ & $6,5-7$ \\
& 3 & $\begin{array}{c}\text { Continental Upper } \\
\text { Mantle }\end{array}$ & $50-100$ & $6,5-8,5$ \\
\hline Oceanic & 1 & Oceanic Crust & $0-18$ & $6,5-7$ \\
plate & 2 & Oceanic Mantle & $18-100$ & $6,5-8,2$ \\
\hline \hline
\end{tabular}

TABLE 3.

SUMMARY OF RESUlTS FROM THE EARTHQUAKE HYPOCENTRE RELOCATION. THE INITIAL AND RECOVERED SOURCE LOCATIONS ARE SHOWN IN FIGURE 2, 3 AND 4.

\begin{tabular}{|c|c|c|c|c|c|c|c|c|}
\hline \multirow{2}{*}{ No } & \multirow{2}{*}{$\begin{array}{l}\text { Date and time } \\
\text { earthquake occurs }\end{array}$} & \multicolumn{2}{|c|}{ Latitude $\left({ }^{0}\right)$} & \multicolumn{2}{|c|}{ Longitude $\left({ }^{0}\right)$} & \multicolumn{2}{|c|}{ Depth (km) } & \multirow{2}{*}{$\begin{array}{c}\text { RMS } \\
(\mathrm{ms})\end{array}$} \\
\hline & & Initial & Recovered & Initial & Recovered & Initial & Recovered & \\
\hline 1 & 2011-02-10T23:19:30 & $-8,4600$ & $-8,4613$ & 112,6400 & 112,6401 & 140,00 & 140,29 & 2,384 \\
\hline 2 & 2011-03-19T01:16:14 & $-8,9400$ & $-8,9427$ & 111,2300 & 111,2300 & 72,00 & 72,26 & 3,321 \\
\hline 3 & 2011-03-20T01:20:16 & $-7,9100$ & $-7,9089$ & 106,7500 & 106,7485 & 46,00 & 45,95 & 3,153 \\
\hline 4 & 2011-03-22Т00:37:17 & $-7,7300$ & $-7,7264$ & 105,9800 & 105,9823 & 5,00 & 4,91 & 2,056 \\
\hline 5 & 2011-04-10T04:14:23 & $-8,8100$ & $-8,8113$ & 108,7900 & 108,7884 & 139,00 & 137,05 & 2,561 \\
\hline 6 & 2011-05-28T20:28:56 & $-8,9600$ & $-8,9615$ & 108,5200 & 108,5179 & 51,00 & 50,96 & 2,384 \\
\hline 7 & 2011-06-11T20:23:09 & $-7,0700$ & $-7,0778$ & 106,1400 & 106,1381 & 5,00 & 6,27 & 3,651 \\
\hline 8 & 2011-06-13T15:46:35 & $-8,1800$ & $-8,1808$ & 110,7600 & 110,7594 & 147,00 & 149,89 & 3,094 \\
\hline 9 & 2011-06-21T22:43:11 & $-6,5700$ & $-6,5717$ & 107,2600 & 107,2594 & 180,00 & 180,63 & 3,552 \\
\hline 10 & 2011-07-01T14:33:25 & $-8,4200$ & $-8,4207$ & 108,6500 & 108,6485 & 90,00 & 90,53 & 2,851 \\
\hline 11 & 2011-07-09T13:27:02 & $-8,8400$ & $-8,8392$ & 108,4300 & 108,4285 & 51,00 & 50,95 & 2,105 \\
\hline 12 & 2011-07-24T08:23:37 & $-7,4100$ & $-7,4111$ & 106,4200 & 106,4190 & 62,00 & 62,13 & 2,384 \\
\hline 13 & 2011-08-21T16:54:21 & $-7,5700$ & $-7,5690$ & 106,6200 & 106,6203 & 63,00 & 65,08 & 4,670 \\
\hline 14 & 2011-08-29T08:56:57 & $-8,2100$ & $-8,2126$ & 107,2300 & 107,2256 & 9,00 & 9,59 & 4,032 \\
\hline 15 & 2011-10-23T17:45:25 & $-8,2300$ & $-8,2288$ & 107,5900 & 107,5883 & 49,00 & 49,02 & 3,270 \\
\hline 16 & 2011-11-06T04:41:56 & $-6,2100$ & $-6,2131$ & 106,2500 & 106,2527 & 162,00 & 162,51 & 2,105 \\
\hline 17 & 2011-12-11T06:34:18 & $-8,2200$ & $-8,2206$ & 107,3100 & 107,3068 & 20,00 & 20,71 & 3,032 \\
\hline 18 & 2012-01-31T04:18:51 & $-8,3400$ & $-8,3406$ & 107,7600 & 107,7610 & 50,00 & 50,03 & 2,441 \\
\hline 19 & 2012-02-03Т04:01:49 & $-8,8300$ & $-8,8291$ & 111,4500 & 111,4504 & 63,80 & 63,94 & 2,384 \\
\hline 20 & 2012-02-15T21:59:30 & $-7,8500$ & $-7,8493$ & 106,1300 & 106,1298 & 70,30 & 70,27 & 2,264 \\
\hline 21 & 2012-02-29T13:28:15 & $-7,5600$ & $-7,5582$ & 106,4900 & 106,4895 & 52,20 & 53,18 & 2,871 \\
\hline 22 & 2012-03-07T15:33:53 & $-7,3800$ & $-7,3774$ & 106,6200 & 106,6210 & 69,30 & 70,35 & 2,411 \\
\hline 23 & 2012-04-12T15:01:20 & $-7,7200$ & $-7,7231$ & 107,1100 & 107,1094 & 63,70 & 64,02 & 2,005 \\
\hline 24 & 2012-05-20T12:37:42 & $-8,3900$ & $-8,3926$ & 107,5200 & 107,5193 & 42,00 & 42,00 & 2,791 \\
\hline 25 & 2012-05-30T04:43:17 & $-8,3500$ & $-8,3496$ & 107,8500 & 107,8500 & 55,00 & 55,12 & 2,067 \\
\hline 26 & 2012-06-04T11:18:15 & $-7,8200$ & $-7,8200$ & 106,2600 & 106,2600 & 82,00 & 80,00 & 2,384 \\
\hline 27 & 2012-08-03T00:57:20 & $-8,0600$ & $-8,0602$ & 107,7100 & 107,7118 & 79,00 & 79,26 & 2,017 \\
\hline 28 & 2012-11-01T14:12:02 & $-7,6100$ & $-7,6102$ & 107,4800 & 107,4840 & 147,00 & 145,72 & 2,473 \\
\hline 29 & 2012-11-10T06:05:27 & $-6,8500$ & $-6,8524$ & 106,5600 & 106,5618 & 52,00 & 52,39 & 2,556 \\
\hline 30 & 2012-12-26T16:12:43 & $-8,0200$ & $-8,0197$ & 107,4900 & 107,4912 & 61,00 & 63,19 & 2,439 \\
\hline
\end{tabular}

\section{CONCLUSION}

We have used a new iterative non-linear tomography scheme to simultaneously invert seismic source datasets for the 3-D seismic structure of the Java island lithosphere.
The deployment of a exceptionally dense temporary seismic network allowed the determination of the crustal structure of Java island at high resolution.

The result of inversion show that there are three layer in $100 \mathrm{~km}$ from the surface at continental plate side (Eurasia). 
The upper crust have $\mathrm{Vp}$ about 4-5,5 $\mathrm{km} / \mathrm{s}$. The lower crust have $\mathrm{Vp}$ 6,5-7 km/s. Upper mantle have $\mathrm{Vp}$ higher value, about $6,5-8,5 \mathrm{~km} / \mathrm{s}$. The oceanic plate (Indo-Australia) have two layer in $100 \mathrm{~km}$ from the surface. The oceanic crust have $\mathrm{Vp}$ about $6,5-7 \mathrm{~km} / \mathrm{s}$. The oceanic mantle have Vp 6,5-8,2 km/s as describe in Table 1 and Table 2. There are low velocity anomaly inclined towards the slab which probably have associated with shallow earthquake along the slab.

\section{ACKNOWLEDGEMENTS}

Catalog data were kindly provided by the Seismological Data Archive/GEOFON of the Geo Forschungs Zentrum Potsdam (GFZ Potsdam). And freeware FMTOMO package that used in this project by Nick Rawlinson Research School of Earth Sciences, Australian National University, Canberra ACT 0200. All figures were created using the freeware software packages GMT. An anonymous reviewer are thanked for their constructtive comments on an earlier version of the manuscript. Essential support of the project was provided by Physics department of Institut Teknologi Sepuluh Nopember (ITS) Surabaya.

\section{REFERENCES}

[1] S. Widiyantoro, Z. Zulhan, A. Martha, E. Saygin, and P. Cummins, "Towards Crustal Structure of Java Island ( Sunda Arc ) from Ambient Seismic Noise Tomography," Geophys. Res. Abstr., vol. 17, p. 2589, 2015.
[2] S. Rohadi, "Studi seismotektonik sebagai indikator potensi gempabumi di wilayah indonesia," J. Meteorol. dan Geofis., vol. 8, no. 1, pp. 111-120, 2007.

[3] S. Widiyantoro and R. van der Hilst, "Mantle structure beneath Indonesia inferred from high-resolution tomographic imaging," Geophys. J. Int., vol. 130, no. 1, pp. 167-182, 1997.

[4] H. Grandis and K. Pengantar, "Pengantar Pemodelan Inversi Geofisika," no. 80, 2009.

[5] T. Lay and T. Wallace, Modern Global Seismology. California: Academic Press, 1995.

[6] M. Sambridge and N. Rawlinson, "Seismic wavefront tracking in 3D heterogeneous media: Applications with multiple data classes MATHEMATICAL GEOPHYSICS View project Seismic wavefront tracking Main in 3D heterogeneous media : applications with Heading multiple data classes," Explor. Geophys., vol. 37, no. 4, pp. 322-330, 2013.

[7] B. L. . Kennett, M. Sambridge, and P. . Williamson, "Subspace methods for large scale inverse problems involving multiple parameter classes," Geophys. J. Int., vol. 94, pp. 237-247, 1988.

[8] A. M. Popovici and J. A. Sethian, "3-D imaging using higher order fast marching traveltimes," vol. 67, no. 2, pp. 604-609, 2002.

[9] M. De Kool, N. Rawlinson, and M. Sambridge, "A practical gridbased method for tracking multiple refraction and reflection phases in three-dimensional heterogeneous media," no. May 1994, pp. 253270, 2006.

[10] N. Rawlinson and B. L. N. Kennett, "Teleseismic tomography of the upper mantle beneath the southern Lachlan Orogen , Australia," vol. 167, pp. 84-97, 2008.

[11] N. Rawlinson and M. Sambridge, "Wave front evolution in strongly heterogeneous layered media using the fast marching method," Geophys. J. Int., vol. 156, pp. 631-647, 2004.

[12] N. Rawlinson and M. Sambridge, "Seismic traveltime tomography of the crust and lithosphere," Adv. Geophys., vol. 46, pp. 81-197, 2003. 